\title{
Dahiliye Polikliniğine Başvuran Bir Grup Hastanın Depresyon ve SomatizasyonDüzeylerinin İncelenmesi
}

\author{
Investigation of Depression and Somatization Levels of a Group of Patients Admitted to \\ Internal Medicine Outpatient Clinic
}

Saban KARAYAGIZ ${ }^{1}$

\section{$\underline{\ddot{O} z}$}

Amaç: Bu çalışmanın amacı dahiliye polikliniğine başvuran ve kronik hastalığı bulunan 55 yaş ve üstü hastaların depresyon düzeylerinin ölçerek; elde edilen sonuçlar ile somatizasyon şiddeti arasındaki ilişkiyi belirlemektir. Ayrıca, Geriatrik Depresyon Ölçeği (GDÖ) ve Beck Depresyon Ölçeği (BDÖ) sonuçları karşılaştııılmıştır.

Araçlar ve Yöntem: Bu prospektif çalışmada kullanılan veriler 2019 yılında üç orta Anadolu ilinde ikamet eden ve dahiliye polikliniğine müracaat eden hastalardan olasılık ve gönüllülük esasına göre toplanmıștır. Veriler, sosyodemografik veri formu, Minnesota Çok Yönlü Kişilik Envanteri (MMPI) somatizasyon alt ölçeği ve depresyon ölçekleri ile toplanmış ve SPSS v20 programı ile analiz edilmiștir. Bireylerin 37'si erkek $(\% 30,6)$ ve 84’ü $(\% 69,4)$ kadın katılımcılardan oluşmuștur.

Bulgular: Katılımcıların yaş aralığı 55 ile 85 arasında $(\operatorname{Ranj}=30)$ ve yaş ortalamaları $58,9 \pm 0,51$ olarak hesaplanmıștır. Dünya Sağlık Örgütü (DSÖ) tarafından 2017 yılında yapılan genç (18 - 65 yaş aralığı), genç yaşlı ( 65 - 74 yaş aralığı) ve yaşlı (75 - 84 yaş aralığı) sınıflandırması göz önüne alındığında; katılımcılar genç ve genç yaşlı ve yaşlı olarak sınıflandırılabilir. GDÖ ve BDÖ araçlarından elde edilen verilerin analizlerinden elde edilen bulgular katılımcıların depresyon seviyeleri arasında ilişkiler olduğunu göstermiştir.

Sonuç: Çalıșmadan elde edilen sonuçlar hastaların çoğunun $(\% 61,16)$ depresif semptomlara sahip olduğunu göstermiștir. Ayrıca, diyabet ve hipertansiyon hastası katılımcıların depresyon şiddetinin daha yüksek; Osteoartrit ve Hiperlipidemi hastalıklarından müzdarip olanlarda ise somatizasyon șiddetlerinin daha yüksek olduğu sonucuna ulașılmıștır. Katılımcıların yaș ve gelir seviyeleri ile depresyon şiddeti arasında zayıf seviyede korelasyon olduğu belirlenmiş, ancak somatizasyon arasında anlamlı bir ilişki elde edilmemiştir. Ayrıca, katılımcıların depresyon șiddetinin ve yaygınlığının (prevalans) yüksekliği dikkat çekmiştir.

Anahtar Kelimeler: depresyon; somatizasyon; kronik hastalık; sosyodemografik özellikler

\section{ABSTRACT}

Purpose: The aim of this study was to measure depression levels of 55 years old and older patients, who applied to internal medicine outpatient clinic and investigate relationship between the results and severity of somatization. Additionally, results of Geriatric Depression Scale (GDS) and Beck Depression Scale (BDI) were compared.

Materials and Methods: This prospective study data was collected on a voluntary basis and randomly from the patients in three central Anatolian provinces. Data were collected using the sociodemographic data form, Minnesota Multiphasic Personality Inventory (MMPI) somatization subscale, and two different depression scales and analyzed using the SPSS v20 program.

Results: 37 of the participants included in the study were male $(30.6 \%)$ and $84(69.4 \%)$ were female. The age range of the participants was calculated between 55 and $85($ Range $=30$ ) and their average age was $58.9 \pm 0.51$. In this context, it can be said that some participants were in middle-aged and others in older-aged groups. Findings obtained from the analysis of the data obtained from the GMO and BDI tools showed that there existed a correlation among the depression levels of the participants.

Conclusion: The findings showed that most patients $(61.16 \%)$ had depressive symptoms. However, participants with diabetes and hypertension had a higher severity of depression. Severity of somatization was higher in those suffering from osteoarthritis and hyperlipidemia. A low correlation was found between their age, income, and depression severity, but no significant relationship existed for somatization criteria. Finally, high levels of depression severity and prevalence were noteworthy.

Key Words: chronic disease; depression; somatization; sociodemographic characteristics

Gönderilme tarihi: 24.03.2020, Kabul edilme tarihi: 07.02.2021

${ }^{1}$ Nuh Naci Yazgan Üniversitesi, Fen-Edebiyat Fakültesi, Psikoloji Bölümü, Kayseri, Türkiye.

Sorumlu Yazar: Dr. Öğr. Üyesi Şaban KARAYAĞIZ, Nuh Naci Yazgan Üniversitesi, Fen-Edebiyat Fakültesi, Psikoloji Bölümü, Kayseri, Türkiye. e-posta: drkarayagiz@yahoo.com 


\section{GíRiş}

Depresyon, çoğunlukla ileri yaştaki insanlarda daha yaygın görülen Mental rahatsızlıklardan birisidir. ${ }^{1}$ Depresyon semptomlarının görülme sıklığı özellikle ilerleyen yaş, cinsiyet, düşük gelir, fiziksel engellik, zihinsel güçlük ve sosyal destek gibi farklı değişkenlere bağlıdır.

Somatizasyon, bireylerin tıbbi olarak belirgin fiziksel bir sorunu olmamasına karşın, kişilerin sağlıkları ile ilgili endişe duymalarının yaşandığı bir bozukluk değil görüngü olarak tanımlanabilir. ${ }^{2}$ Somatizasyon süresi her ne kadar altı ay olarak iddia edilse de, süresi ile beraber şiddeti; bireyin sosyokültürel düzeyi, sorunları ifade edebilme yeteneği, olgun ego savunma düzeneklerini kullanma kabiliyeti ve diğer faktörlere bağlı olarak değişebilmektedir. ${ }^{3}$ Somatizasyon ile ilgili yapılan araştırmalar bu rahatsızlığın daha çok ileri yaşlarda ortaya çıktığını göstermiştir. ${ }^{4,5}$

Depresyon ve somatizasyon bilhassa diyabet veya hipertansiyon gibi kronik hastalığı olan bireylerde daha yaygındır. ${ }^{6}$ Örneğin, yapılan bir çalışmada çoklu somatik şikâyetleri ile tıbbi bozuklukları olan hastalarda klinik depresyon olasılığının göz önünde bulundurulması gerektiğine dikkat çekilmiştir. ${ }^{7}$ Ayrıca, depresyon ile ilgili farklı semptomlara dikkat çekilmiş ve bunlardan farklı olarak doğru depresyon şiddeti ölçümünde farklı ölçekler kullanılabileceği belirtmiştir.

Ulusal ve uluslararası alanda yapılan çalışmalarda araştırmacılar ileri yaşlarda ilk kez ortaya çıkan veya kötüleşen depresyon ve somatizasyon gibi hastalıkların teşhisi ve tedavisinin önemlerini vurgulamışlar ve çeşitli yaklaşımlar ve teoriler ortaya atmışlardır. ${ }^{2,8-11}$

Katon, Kleinman ve Rosen yaptıkları iki kısımlı derleme makalesinde öncelikle somatizasyon ve depresyon arasındaki ilişkiyi ve depresyonun yanlış teşhis edilmesinin nedenlerini ve sonuçlarını incelemişlerdir. ${ }^{12}$ Hastalarda görülen depresyonun somatik tezahürüne ve bunun sonucu olan yanlış teşhisi ortaya çıkarabilen bir model geliştirmişlerdir. Modelde bu durumu etkileyen sosyokültürel faktörler, çocukluk çağı tecrübeleri, duygusal değişiklikler, aile ve sosyal ağlar, çevresel etkiler ve sosyo-politik etkenler gibi değişkenler dahil edilmiştir. Sonuç olarak, hastaların depresyon ve somatizasyon hakkındaki kavram yanılgılarının doktorların depresyon veya somatizasyon bozukluğu teşhisi koyarken onları etkilediğini belirtmişlerdir.

\section{ARAÇLAR ve YÖNTEM}

$\mathrm{Bu}$ prospektif çalışma için 04/04/2019 tarihinde N:004 protokol numarası ile Nuh Naci Yazgan Üniversitesi etik kurulundan onay alınmıştır. Çalışma epidemiyolojik araştırma yöntemlerinden kesitsel araştırma yöntemi ile gerçekleştirilmiştir. Veri toplama sürecinde çalışmaya katılmaya gönüllü olmuş her birey çalışma kapsamında önce sözlü olarak bilgilendirilmiş ardından çalışmaya devam edenlerden aydınlatılmış onam alınmış ve çalışmanın veri toplama sürecinde tüm etik kurallara uyulmuştur.

Veriler 01/06/2019 ile 01/09/2019 tarihleri arasında orta Anadolu illerinde (Kayseri, Ankara, Nevşehir) ikamet eden ve dahiliye polikliniklerine farklı şikâyetler ile başvuran 55 yaş ve üzeri hastalardan elde edilmiştir. Çalışmanın evrenini Kayseri, Ankara ve Nevşehir'de ikamet eden 55 yaş ve üzeri tüm bireyler oluşturmaktadır.

Araştırmanın örneklemi ise üç şehirde bulunan kamu hastaneleri bünyesindeki yerel polikliniklere başvuran kişilerden seçilmiştir. Örnekleme yönteminde polikliniğe başvuran kişilerden gönüllülük esasına göre olasılıklı örnekleme yöntemi ile seçilmiştir. Çünkü polikliniğe başvuran hastalardan çalışmanın amaçlarına uyan kişiler seçilmesi planlanmıştır. Araştırmaya dahil edilen kat1lımcıların 55 ve üstü yaşlarda, bu üç ilden birisinde ikamet eden ve herhangi bir sağlık sebebinden dolayı polikliniğe müracaat etmiş kişilerden olması gerekmektedir. Katılımcıların gelir seviyeleri asgari ücret baz alınarak hesaplanmış ve asgari ücretten daha düşük veya yüksek ise kaç kat yüksek olduğu tespit edilip sınıflandırılmıştır.

Veri toplama işleminde sosyodemografik veri formu ve üç farklı ölçek kullanılmıştır. Somatizasyon alt ölçeği, Minnesota Çok Yönlü Kişilik Envanteri (MMPI) testinden üretilmiş veri toplama aracıdır. Mckinley ve Hathaway tarafindan geliştirilen ve 566 madde içeren MMPI testinin Türkçeye uyarlanması Savaş ve Erol tarafından yapılmıştır. ${ }^{13.15}$ 
Geriatrik Depresyon Ölçeği (GDÖ), Yesavage tarafından yaşlılardaki depresyon seviyesini ölçmek amacıyla geliştirilmiştir. ${ }^{16}$ GDÖ, toplam 30 ifadeden oluşmuş ve '0Hayır ve 1-Evet' seçeneklerini içermektedir. Toplam elde edilebilecek puan aralığ $0-30$ arasındadır. Elde edilen puanlar değerlendirilerek 'depresyon yok' $(0-10)$, 'orta depresyon' (11 - 13), ve 'şiddetli depresyon' (14 ve üzeri) olarak sınıflandırılır.

Beck Depresyon Ölçeği (BDÖ) ise Beck tarafından 1962 y1lında depresyon düzeylerini ölçmek için tasarlanmıştır. $^{17} 13$ yaş ve üzeri bireyler için uygun olan ölçeğin tamamlanması yaklaşı 10 dakika sürmektedir. BDÖ, toplam 21 maddeden oluşan ve 0-3 arası 4'lü Likert cevaplama seçeneklerinden oluşmuştur. Toplam alınabilecek puan 0 ile 63 arasında değişmektedir. Elde edilen puanlar sonucunda depresyon şiddetinin 'minimal $(0-9)$, hafif $(10$ - 16), orta $(17-29)$, şiddetli $(30-63)$ ' seviyelerde olduğu tanımlanmıştır.

Tablo 1. Katılımcıların sosyodemografik özellikleri.

\begin{tabular}{|c|c|c|}
\hline Sosyodemografik Faktör & $\mathbf{N}$ & $\%$ \\
\hline \multicolumn{3}{|l|}{ Cinsiyet } \\
\hline Erkek & 37 & 30,6 \\
\hline Kadın & 84 & 69,4 \\
\hline \multicolumn{3}{|l|}{ Yaş } \\
\hline $51-60$ & 88 & 72,7 \\
\hline $61-65$ & 16 & 13,2 \\
\hline $66-70$ & 6 & 5 \\
\hline 71-75 & 4 & 3,3 \\
\hline $76+$ & 7 & 5,8 \\
\hline \multicolumn{3}{|l|}{ Medeni Durumu } \\
\hline Bekar & 3 & 2,5 \\
\hline Evli & 96 & 79,3 \\
\hline Dul & 22 & 18,2 \\
\hline \multicolumn{3}{|l|}{ Gelir Seviyesi } \\
\hline$<$ Asgari Ücret & 2 & 18,2 \\
\hline$=$ Asgari Ücret & 38 & 31,4 \\
\hline $2 *$ Asgari Ücret & 50 & 41,3 \\
\hline $3 *$ Asgari Ücret & 11 & 9,1 \\
\hline \multicolumn{3}{|l|}{ Eğitim Seviyesi } \\
\hline İlkokul & 49 & 40,5 \\
\hline $\begin{array}{l}\text { Ortaokul } \\
\text { Lise }\end{array}$ & $\begin{array}{l}10 \\
31\end{array}$ & $\begin{array}{l}8,3 \\
25,6\end{array}$ \\
\hline Üniversite & 31 & 25,6 \\
\hline
\end{tabular}

Sosyodemografik form araştırmacılar tarafindan oluşturulmuştur. Katılımcılar ile ilgili elde edilen veriler aşağıdaki tabloda özetlenmiştir. Çalışmanın bağımsız değişkenleri, sosyodemografik özellikler ve bağımlı değişkenlerini ise depresyon ve somatizasyon seviyeleri oluşturmuştur. Evreni temsil eden katılımcılar olasılıklı örnekleme yöntemi ile hesaplanmıştır. Elde edilen veriler ortalama değerler, korelasyon katsayıları ve p-değerleri hesaplanmış ve çalışmanın amaçlarına yönelik olarak kullanılarak analiz edilmiştir. Toplanan veriler SPSS v.20 programı kullanılarak değerlendirilmiştir. ${ }^{18}$

Tablo 1'de gösterildiği gibi katılımcıların çoğu $(\mathrm{N}=84$, $\% 69,4)$ kadındır. Hastaların yaşları ile ilgili verilere bakıldığında çoğunluğun $(88, \% 72,7) 51$ ile 60 yaşları arasında olduğu belirlenmiştir. Medeni durumları açısından ise büyük bir kısmı $(96, \% 79,3)$ evlidir. Katılımcıların yarıdan fazlası asgari ücretin en az iki katı ve üzeri gelirleri olduğunu belirtmişlerdir. Katılımcıların yarısına yakını $(\% 40,5)$ ilkokul mezunudur. Diğer yarısı $(\% 51,2)$ ise lise veya üniversite mezunudur.

\section{BULGULAR}

Bu çalışmada özellikle ileri yaşlarda ortaya çıkan depresyon ve somatizasyon ilişkisi ile beraber her iki rahatsızlık için katılımcıların sosyodemografik özellikleri incelenmiştir. Ayrıca, kronik rahatsızlığı bulunan bireylerin depresyon ve somatizasyon seviyeleri arasındaki ilişkilerde incelenmiş ve analiz edilmiştir. Son olarak, depresyon ölçekleri GDÖ ile BDÖ sonuçları arasındaki bağlantılar araştırılmıştır.

İlk olarak katılımcilar arasında depresyon ve somatizasyon yaygınlığına bakılmıştır. Tablo 2'de elde edilen bulgular özetlenmiştir. Buna göre; BDÖ kullanılarak elde edilen veriler hastaların çoğunda $(\% 61,98)$ hafif, orta ve şiddetli depresyon olduğunu göstermiştir. Benzer şekilde Geriatrik depresyon ölçeğine göre ise hastaların çoğunluğu $(\% 61,16)$ orta ve şiddetli depresyon gruplarına girmektedir. Ayrıca, Tablo 2'deki son üç sütun somatizasyon Ölçeğinden (SÖ) elde edilen bilgileri özetlemektedir. Buna göre katılımcıların çoğunlukla $(\% 61,98)$ üst düzey somatizasyon seviyesine sahiptirler. 
Tablo 2. Katılımciların depresyon (GDÖ, BDÖ) ve somatizasyon (SÖ) seviyeleri ile ilgili istatistiksel ilişkiler.

\begin{tabular}{|c|c|c|c|c|c|c|c|c|}
\hline BDÖ & $\mathbf{N}$ & $\%$ & GDÖ & $\mathbf{N}$ & $\%$ & $\begin{array}{l}\text { MMPI } \\
\text {-SÖ }\end{array}$ & $\mathbf{N}$ & $\%$ \\
\hline Minimum & 46 & 38,02 & $\begin{array}{l}\text { Depresyon } \\
\text { yok }\end{array}$ & 47 & 38,84 & Alt & 0 & 0,00 \\
\hline Hafif & 33 & 27,27 & $\begin{array}{l}\text { Orta } \\
\text { depresyon }\end{array}$ & 15 & 12,40 & Orta & 46 & 38,02 \\
\hline Orta & 34 & 28,10 & $\begin{array}{l}\text { Şiddetli } \\
\text { depresyon }\end{array}$ & 59 & 48,76 & Üst & 75 & 61,98 \\
\hline Şiddetli & 8 & 6,61 & & & & & & \\
\hline
\end{tabular}

\section{Sosyodemografik Özellikler, Depresyon ve} Somatizasyon

Araştırmanın ilk basamağında sosyodemografik veriler 1şığında hastaların depresyon ve somatizasyon verileri bir arada incelenmiştir.

Tablo 3. Katılımcıların Sosyodemografik özellikler ile depresyon (GDÖ, BDÖ) ve somatizasyon (SÖ) seviyeleri arasındaki istatistiksel iliş̧kiler.

\begin{tabular}{|c|c|c|c|}
\hline $\begin{array}{l}\text { Sosyo } \\
\text { demo } \\
\text { grafik } \\
\text { Özellikler }\end{array}$ & Korelasyon & p-değeri & $\begin{array}{l}\text { Ortalama } \\
\text { (SS) }\end{array}$ \\
\hline
\end{tabular}

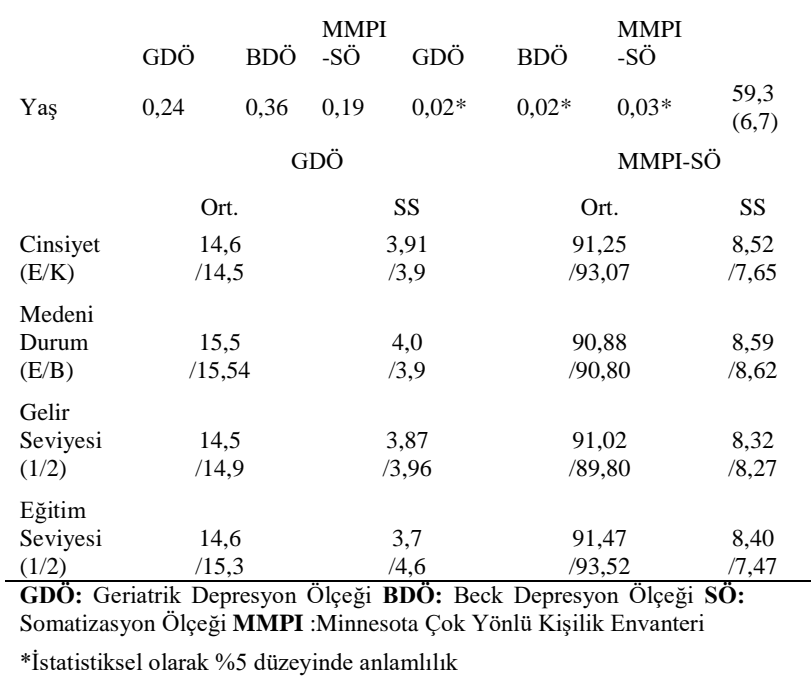

Tablo 3'te sosyodemografik özellikle açısından depresyon ve somatizasyon seviyeleri arasındaki ilişkiler gösterilmiştir. İlk kısımda katılımcıların yaşları ile depresyon ve somatizasyon puanları ile anlamlılık seviyeleri gösterilmiştir. Tablonun alt kısmında ise ölçek puanları ve standart sapmaları Cinsiyet Erkek/Kadın olarak; Medeni durum Evli/Bekar; Gelir Seviyesi ise asgari ücretten düşük (1) ve yüksek olarak (2); Eğitim seviyesi ise Lise ve Ortaokul (1) ile Üniversite ve Lisansüstü (2) olarak sınıflandirılmıştır.

Katılımcıların yaş seviyelerine incelendiğinde hem depresyon hem de somatizasyon seviyeleri açısından istatistiksel olarak anlamlı bir farklılık ( p-değeri $<0,05)$ olduğu belirlenmiştir. Ayrıca, yaş değişkeni ile depresyon ve somatizasyon arasındaki korelasyona bakıldığında ise pozitif çok zayıf korelasyonlar hesaplanmıştır $\left(\mathrm{r}_{\mathrm{GDÖ}}=\right.$ $\left.0,24, \mathrm{r}_{\mathrm{GDÖ}}=0,36, \mathrm{r}_{\mathrm{SÖ}}=0,19\right)$.

Katılımcılara uygulanan GDÖ ve MMPI-SÖ puanları ortalamaları farklı gruplar açısından değerlendirildiğinde kadınların erkeklere göre somatizasyon puanları az da olsa yüksek olmasına rağmen depresyon puanları birbirine yakındır. Evli ve bekar grupların depresyon ve somatizasyon puanları birbirine çok yakın hesaplanmıştır. Benzer şekilde gelir ve eğitim seviyesinin depresyon ve somatizasyon puanlarının kategorisel olarak birbirlerine çok yakın seviyelerde olduğu görülmüştür.

Tablo 4. Katılımcıların yaşları ve Geriatrik Depresyon (GDO), Somatizasyon (SOM) ve Beck Depresyon Ölçekleri sonuçları.

\begin{tabular}{lccc}
\hline Yaş Aralığı (Sayı) & GDO-Ort. & SOM-Ort. & $\begin{array}{l}\text { BDO- } \\
\text { Ort. }\end{array}$ \\
\hline $51-60(\mathrm{~N}=88)$ & 45.65 & 48.39 & 13.07 \\
$61-65(\mathrm{~N}=16)$ & 43.50 & 50.31 & 17.75 \\
& 44.17 & 49.33 & 18.17 \\
$66-70(\mathrm{~N}=6)$ & 43.25 & 51.00 & 25.50 \\
$71-75(\mathrm{~N}=4)$ & & \\
& 42.57 & 50.00 & 23.71 \\
\hline $76(\mathrm{~N}=7)$ & & & \\
\hline $\begin{array}{l}\text { GDÖ: Geriatrik Depresyon Ölçeği BDÖ: Beck Depresyon Ölçeği SOM: } \\
\text { Somatizasyon }\end{array}$ &
\end{tabular}

Araştırma sonuçları ile ilgili bir diğer önemli bulgu kat1lımcıların yaşlarına göre Geriatrik, somatizasyon ve Beck depresyon seviyeleridir. Tablo 4'te gösterildiği gibi katılımcıların yaşları 5 farklı seviyede incelenmiştir. Tablodaki verilere göre 51 ile 60 yaşları arasındaki katılımcıların Geriatrik depresyon ölçeği az da olsa diğer gruplardan daha yüksek olduğu görülmüştür. Ancak, genel olarak değerlendirildiğinde grupların ortalamaları arasındaki fark çok az olduğu belirlenmiştir. Benzer şekilde gruplar arasındaki somatizasyon seviyeleri arasındaki farkların fazla olmadığı görülmüştür. Öte yandan Beck depresyon ölçeğine göre yaş seviyesinin artması depresyon seviyesinin beraberinde artması gibi sonuçlar 
elde edilmiştir. Bir diğer ifadeyle, daha yaşlı insanların depresyon seviyeleri artış göstermekte ancak 76 yaşından sonra ise artış durmaktadır. Gruplardaki katılımcı sayısının azlığından dolayı bu sonuçlar istatistiksel olarak anlamlı olduğunu söylemek güçtür.

Tablo 5. Katılımcıların yaşları ve somatizasyon ve depresyon seviyeleri arasındaki korelasyon katsayıları.

\begin{tabular}{|c|c|c|c|c|c|}
\hline & $\begin{array}{l}\text { GDO } \\
(51-60)\end{array}$ & $\begin{array}{l}\text { GDO } \\
(61-65)\end{array}$ & $\begin{array}{l}\text { GDO } \\
(65-70)\end{array}$ & $\begin{array}{l}\text { GDO } \\
(71-75)\end{array}$ & $\begin{array}{l}\text { GDO } \\
(76+)\end{array}$ \\
\hline $\begin{array}{l}\text { GDO } \\
(61-65)\end{array}$ & 0.02 & 1.00 & & & \\
\hline $\begin{array}{l}\text { GDO } \\
(65-70)\end{array}$ & 0.03 & -0.15 & 1.00 & & \\
\hline $\begin{array}{l}\text { GDO } \\
(71-75)\end{array}$ & 0.15 & 0.01 & 0.35 & 1.00 & \\
\hline \multirow[t]{2}{*}{$\begin{array}{l}\text { GDO } \\
(76+) \\
\end{array}$} & -0.15 & -0.02 & -0.35 & -0.96 & 1.00 \\
\hline & $\begin{array}{l}\text { SOM } \\
(51-60)\end{array}$ & $\begin{array}{l}\text { SOM } \\
(61-65)\end{array}$ & $\begin{array}{l}\text { SOM } \\
(65-70)\end{array}$ & $\begin{array}{l}\text { SOM } \\
(71-75)\end{array}$ & $\begin{array}{l}\text { SOM } \\
(76+)\end{array}$ \\
\hline $\begin{array}{l}\text { SOM } \\
(51-60)\end{array}$ & 1.00 & & & & \\
\hline $\begin{array}{l}\text { SOM } \\
(61-65)\end{array}$ & 0.02 & 1.00 & & & \\
\hline $\begin{array}{l}\text { SOM } \\
(65-70)\end{array}$ & -0.03 & -0.02 & 1.00 & & \\
\hline $\begin{array}{l}\text { SOM } \\
(71-75)\end{array}$ & 0.10 & -0.04 & -0.12 & 1.00 & \\
\hline \multirow[t]{2}{*}{$\begin{array}{l}\text { SOM } \\
(76+)\end{array}$} & -0.13 & -0.10 & 0.03 & -0.02 & 1.00 \\
\hline & $\begin{array}{l}\text { BDO } \\
(51-60)\end{array}$ & $\begin{array}{l}\text { BDO } \\
(61-65)\end{array}$ & $\begin{array}{l}\text { BDO } \\
(65-70)\end{array}$ & $\begin{array}{l}\text { BDO } \\
(71-75)\end{array}$ & $\begin{array}{l}\text { BDO } \\
(76+)\end{array}$ \\
\hline
\end{tabular}

\section{BDO}

(51-60) $\quad 1.00$

BDO

$\begin{array}{lll}(61-65) & -0.04 & 1.00\end{array}$

BDO

$\begin{array}{llll}(65-70) & 0.02 & -0.09 & 1.00\end{array}$

$\begin{array}{lllll}\text { BDO } & & & & \\ (71-75) & 0.09 & -0.40 & -0.07 & 1.00\end{array}$

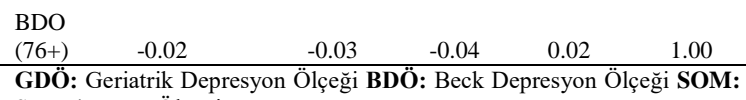
Somatizasyon Ölçeği

Tablo 5'te katılımcıların yaşları ile somatizasyon ve depresyon seviyeleri arasındaki ilişkiler sunulmuştur. Geriatrik depresyon ölçeği 60 yaş altı bireyler için uygun olmadığından dolayı analizden çıkarılmıştır. Tablodaki bilgilerden görüldüğü gibi Geriatrik depresyon ölçeğine göre 71-75 ile 76 ve üzeri yaşlardaki katılımcılar arasında çok yüksek seviyede negatif korelasyon $(\mathrm{r}=-0.96)$ olduğu görülmüştür $65-70$ ve 75 üzeri yaşlardaki katılımcılar arasında düşük negatif ( $\mathrm{r}=-0.35)$ korelasyon elde dilmiş- tir. Ayrıca, 65-70 ve 71-75 yaşları arasında düşük pozitif korelasyon $(\mathrm{r}=0.35)$ olduğu tespit edilmiştir.

Beck depresyon ölçeğine göre katılımcıların yaş grupları arasında depresyon seviyeleri incelendiğinde ise sadece 61-65 ile 71-75 yaş aralığında bulunan katılımcılar arasında düşük negatif korelasyon ( $\mathrm{r}=-0.40)$ elde edilmiştir. $\mathrm{Bu}$ durum iki yaş grubunun depresyon seviyeleri arasındaki ters korelasyonel ilişkiyi göstermiştir. Son olarak yukarıdaki tabloda belirtildiği gibi yaş grupları arasındaki somatizasyon ilişkileri incelendiğinde gruplar arası ilişkilerin son derece düşük korelasyon katsayılarına $(\mathrm{r}<0.20)$ sahip oldukları görülmektedir. Bu sonuç, yaş gruplarının sahip oldukları somatizasyon seviyeleri arasındaki korelasyon ilişkilerinin ihmal edilebilecek seviyede son derece düşük olduğunu göstermiştir.

\section{Kronik Rahatsızlık, Depresyon ve Somatizasyon}

Katılımciların mevcut kronik hastalıkları hasta tanıma için kullanılan sosyodemografik formdan elde edilmiştir. Elde edilen veriler hastaların depresyon ölçekleri (GDÖ, BDÖ) ve somatizasyon ölçeğinden (SOM) elde edilen verilerle karşılaştırılmıştır. Böylece, sahip olunan kronik hastalığın depresyon ve somatizasyon seviyelerine etkileri ortaya çıkarılmıştır.

Tablo 6. Katılımcıların kronik hastalıkları ile depresyon (GDÖ, BDÖ) ve Somatizasyon Ölçeği (SÖ) puanları arasındaki istatistiksel ilișkiler.

\begin{tabular}{|c|c|c|c|c|c|c|c|c|}
\hline \multirow[t]{2}{*}{ Kronik H } & \multicolumn{2}{|c|}{ GDÖ (SS) } & \multicolumn{2}{|c|}{ BDÖ (SS) } & \multicolumn{2}{|c|}{ SÖ (SS) } & \multirow[t]{2}{*}{$\mathbf{N}$} & \multirow[t]{2}{*}{$\%$} \\
\hline & Ort. & SS & Ort. & SS & Ort. & SS & & \\
\hline & & 4,2 & & 4,2 & & 3,7 & 4 & 33,8 \\
\hline Diyabet & 13,37 & 1 & 13,54 & 8 & 15,29 & 4 & 1 & 8 \\
\hline Hipertansi- & & 4,7 & & 4,8 & & 3,8 & 6 & 54,5 \\
\hline & 12,73 & 7 & 14,96 & 9 & 16,01 & 3 & 6 & 5 \\
\hline Hiperlipidem & & 3,1 & & 2,6 & & 3,8 & & \\
\hline $\mathrm{i}$ & 11,44 & 9 & 8,89 & 7 & 16,67 & 5 & 5 & 4,13 \\
\hline Osteoartrit & 11,13 & $\begin{array}{l}4,0 \\
8\end{array}$ & 10,5 & $\begin{array}{l}4,1 \\
2 \\
3,9\end{array}$ & 16,88 & $\begin{array}{l}4,1 \\
1 \\
3,8\end{array}$ & 9 & 7,44 \\
\hline Toplam & 12,17 & 3,9 & 11,97 & 9 & 16,21 & 3 & & \\
\hline
\end{tabular}

Tablo 6'da katılımcıların kronik hastalıkları ile depresyon ve somatizasyon ölçeklerinden elde edilen puanların istatistiksel olarak karşılaştırılması ile elde edilen ortalama puanlar, standart sapmalar ve yüzdeleri gösterilmiştir.

Buna göre katılımcılar dört farklı kronik hastalıktan (diyabet, hipertansiyon, hiperlipidemi, osteoartrit) müzdariptir. Bunlardan en yaygın olanları sırasıyla hiper- 
tansiyon $(\% 54,55)$ ve diyabettir $(\% 33,88)$. Depresyon ölçeklerinden (GDÖ, BDÖ) elde edilen sonuçlar incelendiğinde diyabet ve hipertansiyon hastalarının depresyon seviyelerinin nispeten daha yüksek olduğunu göstermiştir. Hastaların genelinde orta seviyede depresyon olduğu görülmüştür (Ort. (GDÖ) = 12,17, Ort. (BDÖ) = 11,97). Somatizasyon ve kronik hastalıklar arasındaki ilişki açısından; Osteoartrit veya hiperlipidemi hastalıklarına sahip hastalarda az da olsa daha yüksek seviye somatizasyon şiddeti $(16,67$ ve 16,88$)$ elde edilmiştir. Tablo 3 ve Tablo 4'te verilen değerlerde; Geriatrik depresyon ölçeği tam puanı 30, Beck depresyon ölçeği tam puanı 63 ve somatizasyon ölçeği tam puanı 33 olarak belirlenmiştir.

\section{Geriatrik Depresyon Ölçeği ve Beck Depresyon Ölçeği}

Bu çalışmada iki farklı depresyon ölçeğinden yararlanılmıştır. Her iki ölçek depresyon seviyelerini ölçmekte kullanılsa da Geriatrik depresyon ölçeği daha çok ileri yaşlardaki (60 ve üzeri) hastalara uygulanmaktadır.

Tablo 3'te belirtildiği gibi katılımcıların sosyodemografik verileri depresyon ve somatizasyon puan ortalamaları ile ilgili istatistiksel bilgiler sunulmuştur. Katılımcıların ortalama yaş seviyesi ve standart sapma puanları 59,3 ve 6,7 olarak bulunmuştur. Yaş seviyeleri ile ölçek puanları incelendiğinde GDÖ, BDÖ ve MMPI puanları arasında düşük pozitif, $0,24,0,36,0,19$, korelasyon katsayıları olduğu belirlenmiştir. Ayrıca, her üç ölçek ile yaş seviyeleri arasında istatistiksel olarak anlamlı bir farklılık (pdeğeri $<0,05$ ) olduğu görülmüştür. Tablo 3 'teki ikinci kısımda ise ölçek depresyon ve somatizasyon puanlarının sosyo-demografik özellikler bağlamında değerlendirilmiştir. Cinsiyet $(14,6 / 14,5)$ ve medeni durum $(15,5 / 115,5)$ açısından depresyon seviyeleri erkek/kadın ve evli/bekar grupları için birbirine yakın seviyelerde hesaplanmıştır. Gelir seviyesi ve eğitim seviyesi açısından ise asgari ücretten yüksek gelire sahip $(14,9)$ ve üniversite eğitimi almış kişilerin $(15,3)$ depresyon seviyeleri daha yüksektir. Son olarak, somatizasyon seviyeleri incelendiğinde ise kadınların daha yüksek puan ortalamasina $(93,07)$ olduğu görülmüştür. Medeni durum olarak evli ve bekarların ortalama somatizasyon seviyesi benzerdir. Gelir seviyesi asgari ücretten düşük olan grup $(91,02)$ ve eğitim seviyesi üniversite seviyesine sahip grubun $(93,52)$ ortalama somatizasyon seviyesinin daha yüksek olduğu belirlenmiştir.

\section{TARTIŞMA}

$\mathrm{Bu}$ araştırma sonucunda elde edilen bulgularda katılımc1lar arasında depresyon ve somatizasyon yaygınlı̆̆ının (prevalans) yüksek olduğu görülmüştür. Bulgular daha önce elde edilen araştırma sonuçlarına benzerlik göstermektedir. $^{19,20}$

Araştırma bulguları katılımcıların sosyodemografik olarak yaş, eğitim seviyesi ve gelirlerinin yükselmesinin depresyon ve somatizasyon seviyelerini artırdığını göstermiş̧ir. Cinsiyet açısından elde edilen benzer sonuçlar daha önce mental rahatsızlıklar ile sosyodemografik özellikler arasındaki ilişki ile ilgili yapılan çalışmalardan daha farklıdır, ancak gelir seviyesi, eğitim ve evlilik durumları açısından benzer bulgular elde edilmiştir. ${ }^{21-23}$ Cinsiyet açısından daha önce yapılan çalışmalarda istatistiksel olarak anlamlı bir farklılık ortaya konulmasına rağmen bu çalışmada elde edilen sonuçlar cinsiyet açısından depresyon ve somatizasyon seviyeleri arasında istatistiksel olarak anlamı bir farklılık olmadığı görülmüştür. Benzer şekilde farklı yaş grupları karşılaştırıldığında depresyon ve somatizasyon ortalamaları arasında istatistiksel olarak anlamlı bir farklılık bulunmamaktadır. Bunun en önemli sebebi gruplarda yeteri kadar fazla sayıda katılımcı olmaması olabilir. Bu bağlamda daha geniş kitlelerle yapılacak çalışmalara ihtiyaç duyulmaktadır.

Çalışmada incelenen bir diğer başlık katılımcı yaş gruplarına göre depresyon ve somatizasyon seviyeleri arasındaki korelasyonel ilişkilerdir (Tablo 5). Elde edilen sonuçlarda Geriatrik depresyon ölçeğine verilen cevaplara göre 71-75 ile 76 ve üzeri yaşlardaki katılımcılar arasında çok yüksek seviye negatif korelasyon belirlenmiştir. Benzer diğer bir sonuç ise Beck depresyon ölçeğine göre 61-65 ile 71-75 yaş aralığında bulunan katılımcılar arasında bulunmuştur. Buna göre yaş gruplarını ayıran 75 yaş ile 65-70 yaşları arasındaki periyod depresyon seviyesi açısından sınır kabul edilebilir. Bireylerde bu yaştan sonra depresyon seviyelerinde ters yönde bir yöneliş olduğu söylenebilir. Ayrıca, yaş grupları arasındaki somatizasyon ilişkileri son derece düşük korelasyon seviyeleri göstermiştir. Bu sonuç, çalışmada incelenen 
yaş gruplarının sahip oldukları somatizasyon seviyeleri arasında ilişki bulunmadığını göstermiştir. Elde edilen bu sonuçlar daha önce yapılan çalışmalarda belirlendiği gibi depresyon seviyeleri ileriki yaşlarda azalmaktadır. ${ }^{24-26}$

Kronik rahatsızlık, depresyon ve somatizasyon sonuçları değerlendirildiğinde özellikle diyabet ve hipertansiyona sahip hastaların depresyon seviyeleri, Osteoartrit ve Hiperlipidemi hastalığa sahip olanlarda ise somatizasyon seviyeleri yüksektir. Ayrıca, herhangi bir kronik rahatsızlığı olan bireylerde bu rahatsızlıkların depresyon ve somatizasyona sahip olmalarını etkilemediği sonucuna daha önce yapılmış olan çalışma sonuçlarına paralel olarak erişilmiştir. ${ }^{7,27}$

$\mathrm{Bu}$ çalışmadan elde edilen bulgular daha önce yapılmış çalışmalarla benzerlik gösterse de çoğu çalışmada elde edilen verilerden yüksek oranlarda depresyon tespit edilmiştir. Bunun sebebi veri toplanan grubun sosyal, kültürel, çevresel, demografik ve diğer depresyon ve somatizasyon ile ilgili faktörlerden kaynaklanabileceği söylenebilir.

Gelecek yıllarda yapılacak çalışmalar depresyon seviyesi yüksek olan kişilerin yapılandırılmış klinik görüşme ile değerlendirilmeli ve psikiyatristlere yönlendirilerek teşhisin netleştirilmesi ülkemizde ileri yaşlarda sıklıkla görülen depresyona karşı geliştirilecek yaklaşımlar için gereklidir. Ayrıca ileride yapılacak çalışmalar için kontrol grubu kullanılması ve bu şekilde toplumdaki genel depresyon oranı ile değerlendirerek hastalıkların neden olduğu depresyon oranı ile ilgili daha zengin bilgiler edinilebilir.

\section{Çıkar Beyannamesi}

Yazar herhangi bir çıkar çatışması olmadığını beyan etmektedir.

\section{KAYNAKÇA}

1. Blazer D, Burchett B, Service C, George LK. The association of age and depression among the elderly: an epidemiologic exploration. J Gerontol. 1991;46(6):210-215.

2. Kesebir S. Depresyon ve somatizasyon. Turk Psikiyatri Derg. 2004;1(1):14-19.

3. Lipowski ZJ. "Somatization and Depression". Psychosomatics. J of Cons and Liaison Psych. 1990; 31(1):13-21.
4. Wilson DR, Widmer RB, Cadoret RJ. Somaticsymptoms: a major feature of depression. J Affect Disord. 1983;5(3):199207.

5. Howard R. Syndromes of depression in the elderly. Howard R (Ed). Depression in Elderly People. 1.ed. United Kingdom: Martin Dunitz Ltd;1997:33-34.

6. Finkelstein EA, Bray JW, Chen H, Larson MJ, Miller K, Tompkins C. Prevalence and costs of major depression among elderly claimants with diabetes. Diabetes care. 2003;26(2):415-420.

7. Drayer RA, Mulsant BH, Lenze EJ, Rollman BL, Dew MA, Kelleher K. Somatic symptoms of depression in elderly patients with medical comorbidities. Int $\mathrm{J}$ Geriatr Psychiatry. 2005;20(10):973-982.

8. Özenli Y, Yoldaşcan E, Topal K, Özçürümez G. Türkiye'de bir eğitim fakültesinde somatizasyon bozukluğu yaygınlığı ve ilişkili risk etkenlerinin araştırılması. Anadolu Psikiyatri Derg. 2009;10(Suppl 2):131-136.

9. Çermik Ö, Çevik A, Soykan A, Aksakal O. Kadın hastalarda somatizasyon: çok yönlü bir değerlendirme. Turk Psikiyatri Derg. 1999;1(1):68-78.

10. Sheehan B, Banerjee S. Somatization in the elderly. Int $J$ Geriatr Psychiatry. 1999;14(12):1044-1049.

11. Van Driel TJW, Hilderink PH, Hanssen DJC, et al. Assessment of somatization and medically unexplained symptoms in later life. Assessment. 2018;25(3):374-393.

12. Katon W, Kleinman A, Rosen G. Depression and somatization: a review. Am J Med. 1982;72(2):241-247.

13. Savaşır I. Minnesota Çok Yönlü Kişilik Envanteri El Kitabı. Ankara:Sevinç Matbaası;1981.

14. Erol N. Ülkemizdeki psikiyatrik hastalarda MMPI'ın geçerlik çalışması. Psikoloji Der. 1982;14(2):15-23.

15. Hathaway SR, McKinley JC. A multiphasic personality schedule (Minnesota): I. Construction of the schedule. J of Psychol. 1940;10(2):249-54.

16. Yesavage JA, Brink TL, Rose TL. Development and validation of a geriatric depression screening scale: a preliminary report. J Psychiatry Res. 1983;17(1):37-49.

17. Beck AT, Ward C, Mendelson M, Mock J, Erbaugh J. Beck depression inventory (BDI). Arch Gen Psychiatry. 1961;4(6):561-571.

18. IBM Corp. Released 2011. IBM SPSS Statistics for Windows, Version 20.0. Armonk, NY: IBM Corp.

19. Pang KY, Lee MH. Prevalence of depression and somatic symptoms among Korean elderly immigrants. Yonsei Med J. 1994;35(2):155-161.

20. Bland RC, Newman SC, Orn H. Prevalence of psychiatric disorders in the elderly in Edmonton. Acta Psych Scand. 1988;77(S338): 57-63.

21. Klose M, Jacobi F. Can gender differences in the prevalence of mental disorders be explained by sociodemographic factors?. Arch of W.M.H. 2004;7(2):133-148.

22. Araya R, Rojas G, Fritsch R, Acuña J, Lewis G. Common mental disorders in Santiago, Chile: prevalence and sociodemographic correlates. Br J Psychiatry. 2001;178(3):228233.

23. Akhtar-Danesh N, Landeen J. Relation between depression and sociodemographic factors. Int $\mathrm{j}$ Ment Health Syst. 2007;1(4):1-9.

24. Fiske A, Wetherell JL, Gatz M. Depression in older adults. Annu Rev Clin Psychol. 2009;5:363-389.

25. Rodda J, Walker Z, Carter J. Depression in older adults. BMJ. 2011;343:683-687.

26. Cuijpers P, Karyotaki E, Pot AM. Managing depression in older age: psychological interventions. Maturitas. 2014;79(2):160-169.

27. Palinkas LA, Wingard DL, Barrett-Connor E. Chronic illness and depressive symptoms in the elderly: a population-based study. J Clin Epidemiol. 1990;43(11):1131-1141. 